\title{
Complete avulsion of the optic nerve A clinical, angiographic, and electrodiagnostic study
}

\author{
JEFFREY S. HILLMAN, V. MYSKA, AND SARAH NISSIM \\ From the Angiography and Retina Departments, Birmingham and Midland Eye Hospital
}

The optic nerve may be damaged in trauma to the head either with or without fracture, and sometimes after an apparently trivial injury. The intracranial portion of the nerve is rarely involved because of its relative mobility but optic atrophy from damage to the intracanalicular or intraorbital portions is well documented. The mechanism of damage in the canal is by extension of bone fracture, direct penetration of a foreign-body, or by shearing forces tearing the pial covering of the nerve. Damage in the orbit usually follows the penetration of a foreign-body.

Damage may also occur at the disc, the suggested mechanisms being by anterior luxation of the globe, retropulsion of the nerve, forced globe rotation, or a sudden explosive rise in intraocular pressure blowing the nerve off the sclera into its dural sheath like a cork from a bottle. A case of partial rupture of the lamina cribrosa after blunt injury was reported by Lang (190I). There have been a number of similar case reports and we have reviewed papers by Goldsmith (1903), Hesse (1907), Birkhäuser (I9IO), Pichler (I9IO), Gonin (I9I2), Treacher-Collins (I9I4), Juler (I9I6), Loewenstein (1943), Spizziri (1964), Kommerell (1966), Hart and Pilley (1970), and Park, Frenkel, Dobbie, and Choromokos (1971). The last two papers reported fundus fluorescein angiography findings.

The first full clinical description of complete avulsion of the optic nerve was by Salzmann (1903) who adopted the term 'Evulsio nervi optici' and who gave credit for the first case presentation to Aschmann (1884). Further case reports have been made by Gagarin (1904), Weinstein (r908), Stoewer (1910), Lister and Hine (1919), Gruber (1959), and Kovács (197I). The true incidence of both partial and complete avulsion of the optic nerve is undoubtedly greater than is suggested by these cases reported over 90 years. Extensive vitreous haemorrhage usually delays or prevents clinical diagnosis in the early stages and the late Address for reprints: The Birmingham and Midland Eye Hospital,
Church Street, Birmingham $\mathrm{B}_{3} 2 \mathrm{NS}$ stage may be confused with developmental anomaly (Frost, 1903; Stanton-Cook, 1953). The absence of major haemorrhage allowed a definite diagnosis of complete avulsion to be made in the accident unit in this case, which is presented as the first case of complete avulsion of the optic nerve followed-up clinically and by serial fluorescein angiography, electroretinography, and visually evoked cortical responses to investigate the effects upon retinal circulation and function.

\section{Case report}

I APRIL 1974

A 26-year-old woman was the front passenger of a car involved in a collision. She hit her head against the dashboard as she was not wearing a seat belt and became unconscious. On arrival at the general accident unit she was fully conscious with bruising to the left shoulder, upper arm, and ribs. $X$ rays confirmed minor fractures of the left malar bone, second rib, and the little finger. The left cheek was swollen and tender, there were lacerations to the side of the mouth, and the left eye was noted to be blind.

Ophthalmological examination I4 hours after injury revealed a normal right eye but a left eye with bruising of both lids, ptosis, and no perception of light. The cornea was bright, the anterior chamber clear, and the pupil semidilated exhibiting brisk consensual but absent direct light reflexes. The vitreous was clear and the disc replaced by a deep round hole with a clear sharp rim surrounded by an apparently bared ring of sclera one disc diameter wide, Fig. I. Despite a little preretinal haemorrhage the retina was seen to be flat with patent branch retinal vessels which could not be traced back across the bared area into the disc hole. There was no sign of the central retinal vessels which appeared to have retracted into the hole. The intraocular pressures were normal and equal to digital assessment, there was no proptosis, and the external ocular movements were full.

\section{APRIL 1974}

The posterior pole of the left fundus was oedematous and the circulation in the branch retinal vessels was 
visibly reduced with fragmentation of the blood columns ('Cattle-trucking').

9 APRIL 1974

The left fractured zygoma was raised via a Caldwell-Luc approach.

\section{7 APRIL 1974}

The disc hole was unchanged, the retina flat, and the branch retinal vessels appeared to be normal.

\section{Fluorescein angiography}

The circulation was normal in the major retinal vessels but appeared to stop at the edge of the bared area without continuity into the disc hole. The bared area presented a collection of irregular choroidal vessels, one of which joined the superior temporal artery at right-angles (Fig. 3). Leakage of fluorescein occurred from these irregular vessels staining the bared area and the disc hole (Fig. 4).

\section{Electroretinography}

Devices 3182 photic stimulator, Lovac scleral electroretinography contact lens, Devices 3542 high gain amplifiers frequency range $1 \cdot 0 \mathrm{~Hz}$ to $100 \mathrm{~Hz}$.

Right eye-Normal response, a-wave $190 \mu \mathrm{V}$, b-wave $440 \mu \mathrm{V}$.

Left eye-Reduced and delayed response, a-wave I $70 \mu \mathrm{V}$, b-wave $200 \mu \mathrm{V}$.

(Measurements from the I0-min scotopic high intensity flash recordings (Fig. 5)).

\section{Visually-evoked cortical responses}

Devices 3182 photic stimulator, Medelec MS6 Unit, amplifiers frequency range $0.8 \mathrm{~Hz}$ to $500 \mathrm{~Hz}$.

Right eye-Within normal limits.

Left eye-No response. (Fig. 6).

\section{JUNE 1974}

The disc hole was almost completely filled with white connective-tissue obscuring the previously-sharp rim. A pigment ring had appeared along the outer lip of the bared area except between 4 and 6 o'clock where the retina was locally tented in a white veil-like formation.

\section{Fluorescein angiography}

The retinal vessels filled normally and then curled proximally around the edge of the torn retina to disappear into the choroid around the edge of the connectivetissue mass. This mass showed fluorescein staining centrally and leaking fine irregular choroidal vessels peripherally (Fig. 7).

\section{Lid electroretinography}

Lower lid skin electrode, Devices 3182 photic stimulator, Medelec MS6 Unit, amplifiers frequency range $0.8 \mathrm{~Hz}$ to $500 \mathrm{~Hz}$.

Right eye-Normal response, a-wave $10 \mu \mathrm{V}, \mathrm{b}$-wave $40 \mu \mathrm{V}$.

Left eye-Reduced response, a-wave $1 \circ \mu \mathrm{V}$, b-wave IouV.

(Measurements from the 10-min scotopic high intensity flash recordings).

\section{Visually-evoked cortical responses}

Right eye-Within normal limits.

Left eye-Suspicion of low amplitude $3 \mu \mathrm{V}$ positive component around I Io msec.

I JULY 1974

Retinal haemorrhages had disappeared leaving the retina flat apart from local tenting beside the disc hole.

20 JULY 1974

Extensive retinal detachment radiating from the edge of the disc connective-tissue mass between 3 and 7 o'clock.

\section{Fluorescein angiography}

This showed patent retinal vessels. Profuse staining of the disc connective-tissue mass with fluorescein could be seen.

\section{Electroretinography}

Right eye-Normal response, a-wave $\mathrm{I} 60 \mu \mathrm{V}$, b-wave $4 \mathrm{Io \mu V}$.

Left eye-Reduced response, a-wave $25 \mu \mathrm{V}$, b-wave $65 \mu \mathrm{V}$.

(Measurements from the ro min scotopic high intensity flash recordings, Fig. 8).

\section{Visually-evoked cortical responses}

Right eye-Within normal limits. Left eye-No response.

\section{SEPTEMBER I 974}

Connective-tissue completely filled the disc hole and thick retinal folds radiated from its edge between 2 and 7 o'clock. The retinal vessels were patent, Fig. 2.

FIG. I Fundal appearance 17 days after traumatic complete avulsion of optic nerve. Disc replaced by round hole surrounded by area of apparently bared sclera

FIG. 2 Fundal appearance 5 months after complete avulsion of optic nerve. Disc hole filled with connective-tissue. Retina lying in thick folds 


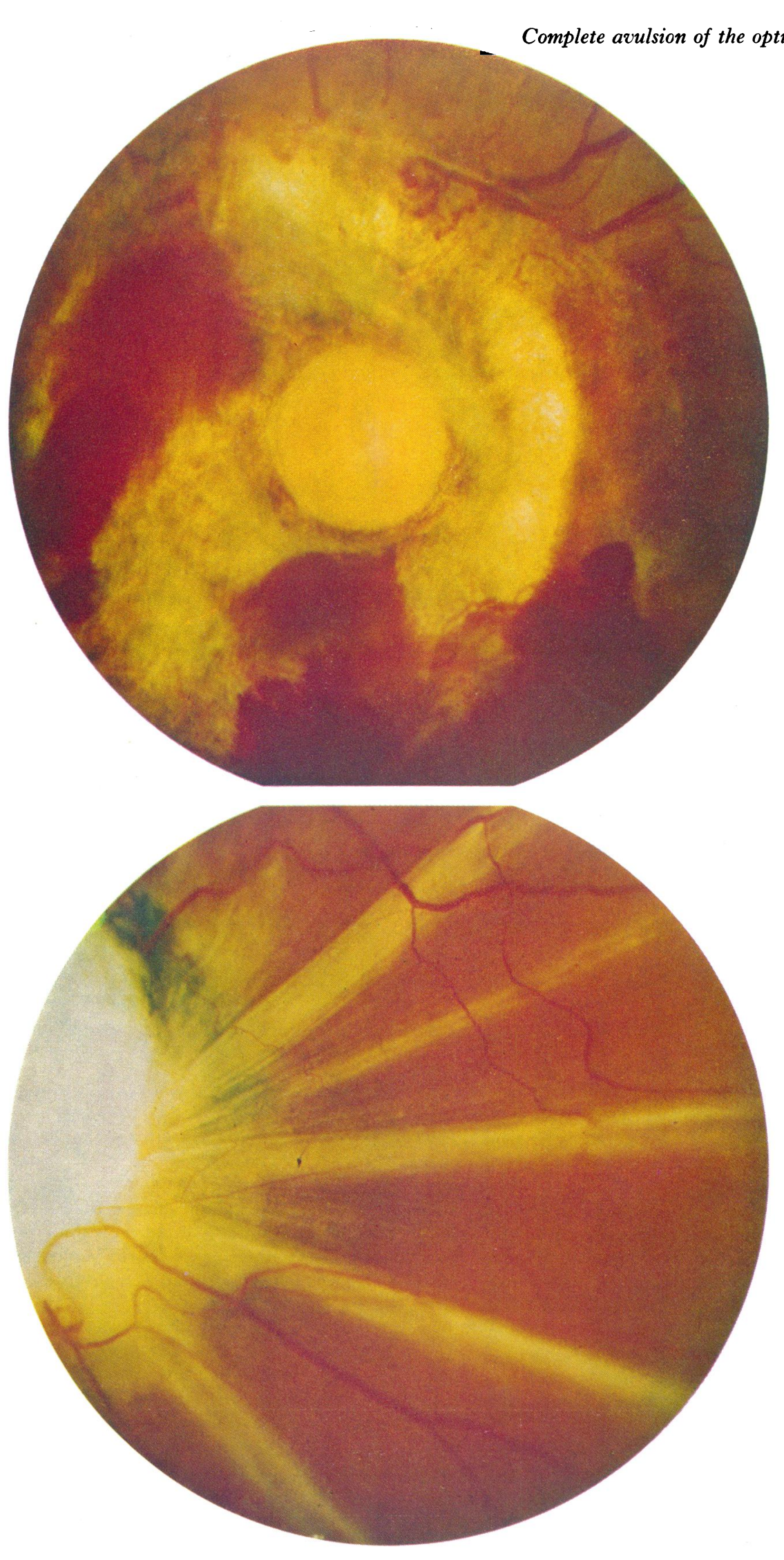




\section{Electroretinography}

Right eye-Normal response, a-wave $230 \mu \mathrm{V}$, b-wave $5 \mathrm{I} O \mu \mathrm{V}$.

Left eye-Reduced response, a-wave $50 \mu \mathrm{V}$, b-wave $9 \circ \mu \mathrm{V}$.

(Measurements from the ro min scotopic high intensity flash recordings).

\section{Discussion}

The clinical progress of this case closely followed the first description by Salzmann (1903). The disc was replaced by a hole surrounded by an area of apparently-bared sclera and over the next 2 months this hole filled with white connective tissue. Local tenting of the retina at the edge of the hole produced a white veil-like appearance which has been described in the past as an extension of the connective tissue into the retina. The circulation in the branch retinal arteries and veins appeared to be good apart from an early transient disturbance. This was surprising as these vessels could be traced to the edge of the bared area where they had been divided from the central retinal vessels.

The circulatory changes of the cases reported in the literature are summarized in the Table. Salzmann (1903) and Gagarin (1904) both described branch retinal vessels which were filled with blood despite having lost continuity with the central retinal vessels in the disc hole, as in our case. Salzmann (1903) suggested the possibility of anastomosis between the choroidal and retinal vessels

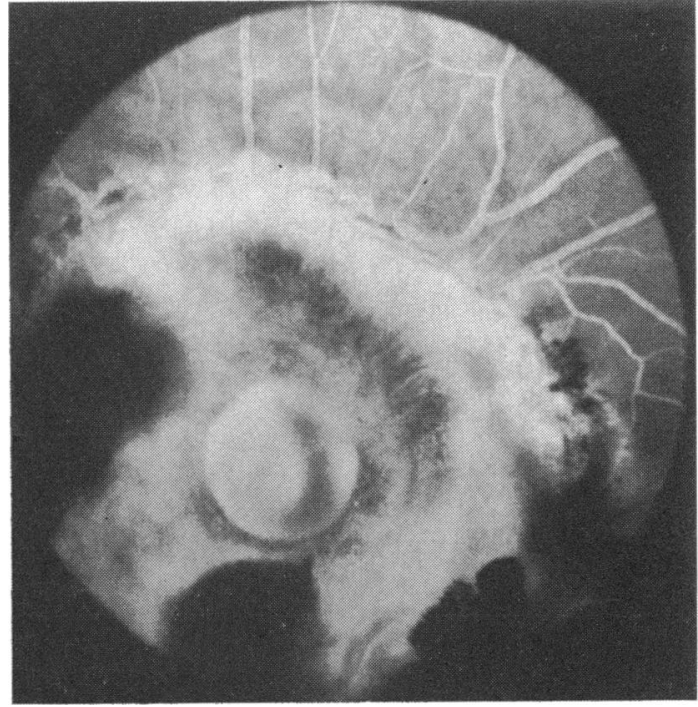

FIG. 4 Fluorescein angiography (venous phase) I 7 days after complete avulsion of optic nerve. Leakage of fluorescein shown from irregular choroidal vessels. Disc hole and bared area staining with fluorescein

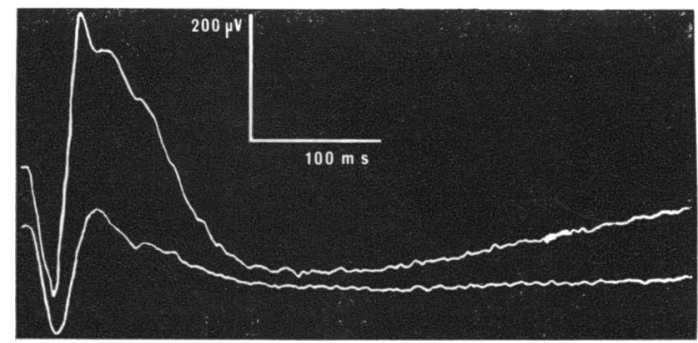

FIG. 5 10 min scotopic electroretinogram to high intensity flash 17 days after complete avulsion of optic nerve. Retina flat.

Right eye: Normal response a-wave I $90 \mu V, b$-wave $440 \mu V$.

Left eye: Reduced response a-wave I $70 \mu V, b$-wave $200 \mu V$

to explain the maintenance of the circulation, and Stoewer (I910) supported this theory. Pichler (I9I0) reported seeing a vessel communicating between the choroidal vessels in the bare area and the retina.

Fundus fluorescein angiography has been reported in two cases of partial avulsion of the optic nerve. Hart and Pilley (1970) found delayed filling and emptying of veins in the affected quadrant with leakage of fluorescein from the damaged nerve and Park and others (1971) found no abnormality in their case. Angiography in our case of complete avulsion confirmed normal circulation in the branch retinal vessels and a communication was shown between peripapillary choroidal vessels and 


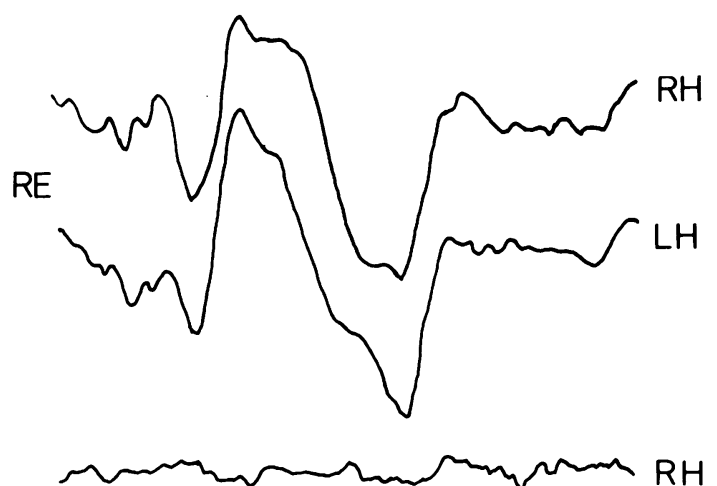

LE

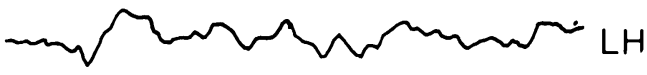

FIG. 6 Visually evoked cortical responses. Right eye $(R E)$ normal response. Left eye ( $L E)$ no response. $R H$ shows trace from right hemisphere, $L H$ shows trace from left hemisphere

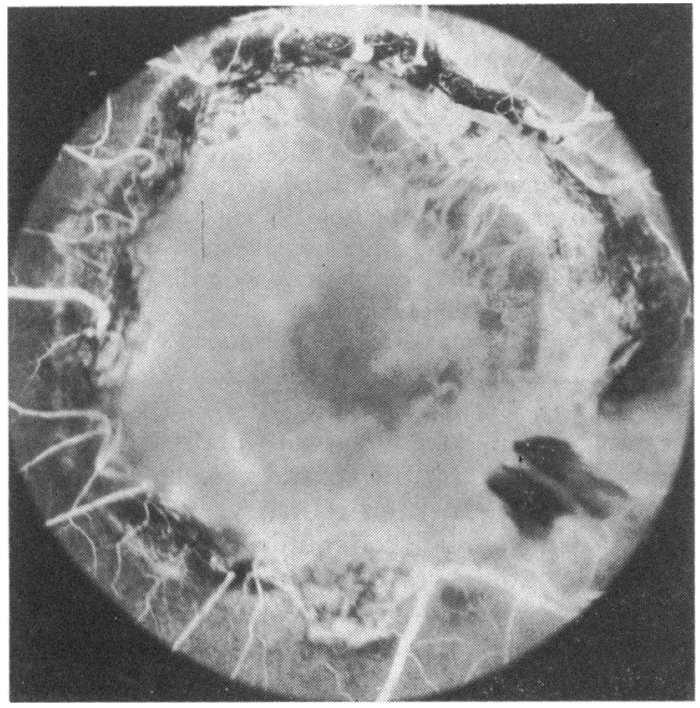

FIG. 7 Fluorescein angiography 9 weeks after complete avulsion of optic nerve. Disc hole filled with connectivetissue. Retinal vessels shown curling around edge of retina

the superior temporal retinal artery. Although it has been suggested that both circulations may contribute to the blood supply of the optic disc, the existence of communication between the choroidal circulation and branch retinal arteries is not traditionally accepted. With the disappearance of the central retinal vessels such communication appears to be the only possible route for the maintenance of retinal circulation.

It has been suggested that the optic nerve may

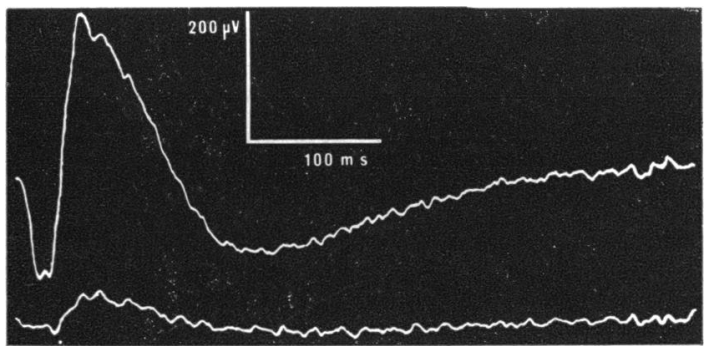

FIG. 8 Io min scotopic electroretinogram to high intensity flash 8 weeks after complete avulsion of optic nerve. Retina detached.

Right eye: Normal response a-wave $160 \mu V, b$-wave $4 \mathrm{I} 0 \mathrm{\mu V}$.

Left eye : Reduced response a-wave $25 \mu V, b$-wave $65 \mu \mathrm{V}$

contain centrifugal fibres which exert an inhibitory effect upon the retina. Many studies have been made of electroretinography after optic nerve transection and the results have been conflicting. Jacobson and Gestring (1958) found increased electroretinogram amplitude after optic nerve transection in lightlyanaesthetized cats. Jacobson and Suzuki (1962) transected cat optic nerves and found that the electroretinogram response to the second of a double-flash stimulus exceeded that to the first flash, the reverse of that with intact optic nerve. Brindley and Hamasaki (1962) found that optic nerve transection with or without anaesthesia in cats had no effect upon the electroretinogram. Gills (1966) investigated two cases of old optic nerve transection in man and obtained higher electroretinogram responses than in the intact fellow eyes. Nagaya, Oishi, and Kuno (1962) studied optic nerve transection in 20 cats by double-flash electroretinography and obtained results in support of centrifugal optic nerve fibres. Brindley and Hamasaki (r 966) sectioned cat optic nerves and found no histological evidence in support of centrifugal fibres. Horsten and Winkelman (r969) obtained normal serial electroretinograms for $I \frac{1}{2}$ hours after stereotactic destruction of the optic nerve in a newborn puppy. van Hasselt (1969) studied double-flash electroretinograms after optic nerve transection in unanaesthetized rabbits and found results supporting the existence of centrifugal fibres.

The different results obtained in these studies may reflect the use of different experimental animals, electrodiagnostic equipment, or techniques, and van Hasselt (1972) reviewed the literature extensively in an attempt to reveal possible sources of error or misinterpretation. In our case of complete optic nerve avulsion electroretinography on the seventeenth day showed a normal a-wave but a b-wave amplitude reduced by $54^{\circ} 5$ per cent compared with the intact fellow eye. At this 
Table Review of retinal vascular disturbances in cases of partial $(P)$ and complete $(C)$ avulsion of optic nerve reported in literature

\begin{tabular}{|c|c|c|c|c|c|}
\hline Paper & Date & & Degree & Injury & Retinal vascular disturbance \\
\hline Aschmann & I 884 & & $\mathrm{C}$ & $?$ & Pathological report only \\
\hline Lang & I 901 & & $\mathbf{P}$ & Clothes-prop & Nil \\
\hline Salzmann & 1903 & & $\mathrm{C}$ & Revolver shot & $\begin{array}{l}\text { Normal calibre vessels stopping at edge of } \\
\text { disc hole }\end{array}$ \\
\hline Goldsmith & 1903 & & $\mathbf{P}$ & Wood & Vessels continue into hole \\
\hline Gagarin & 1904 & $\begin{array}{l}\text { Rt } \\
\mathrm{Lt}\end{array}$ & $\begin{array}{l}\mathrm{C} \\
\mathrm{C}\end{array}$ & $\begin{array}{l}\text { Horsekick } \\
\text { Horsekick }\end{array}$ & $\begin{array}{l}\text { Vitreous haemorrhage-no view } \\
\text { Normal calibre vessels not continuing into hole }\end{array}$ \\
\hline Hesse & 1907 & & $\mathrm{P}$ & Stick & Hyphaema-no view \\
\hline Weinstein & 1908 & $\begin{array}{l}\text { Rt } \\
\mathrm{Lt}\end{array}$ & $\begin{array}{l}\mathrm{C} \\
\mathrm{C}\end{array}$ & $\begin{array}{l}\text { Revolver shot } \\
\text { Revolver shot }\end{array}$ & $\begin{array}{l}\text { Vitreous haemorrhage-no view } \\
\text { Vessels attenuated }\end{array}$ \\
\hline Birkhäuser & 1910 & & $\mathrm{P}$ & Cow's horn & $\begin{array}{l}\text { Arteries thin-veins dilated } \\
\text { Vessels not continuous with disc }\end{array}$ \\
\hline Stoewer & 1910 & $\begin{array}{l}\text { I } \\
2\end{array}$ & $\begin{array}{l}\mathrm{C} \\
\mathrm{C}\end{array}$ & $\begin{array}{l}\text { Umbrella } \\
\text { Stick }\end{array}$ & $\begin{array}{l}\text { Arteries collapsed-veins dilated } \\
\text { Peripheral vessels patent }\end{array}$ \\
\hline Pichler & 1910 & & $\mathrm{P}$ & Horsekick & Vessels not continuous with hole \\
\hline Gonin & 1912 & $\begin{array}{l}\mathbf{I} \\
\mathbf{2}\end{array}$ & $\begin{array}{l}\mathrm{P} \\
\mathrm{P}\end{array}$ & $\begin{array}{l}\text { Ski } \\
\text { Ruler }\end{array}$ & $\begin{array}{l}\text { Nil } \\
\text { Nil }\end{array}$ \\
\hline Treacher-Collins & 1919 & & $\mathrm{P}$ & Bat & $\begin{array}{l}\text { Affected vessel convoluted and not reaching } \\
\text { disc }\end{array}$ \\
\hline Juler & 1916 & & $\mathbf{P}$ & Stone & $\begin{array}{l}\text { Arteries narrow-veins normal ending some } \\
\text { distance from the disc }\end{array}$ \\
\hline Lister and Hine & 1919 & & $\mathrm{C}$ & Shrapnel & $\begin{array}{l}\text { Vessels attenuated-fundus drawing shows } \\
\text { vessels failing to reach hole }\end{array}$ \\
\hline Loewenstein & 1943 & & $\mathbf{P}$ & Nail & Not recorded-? nothing abnormal discovered \\
\hline Gruber & I 959 & & $\mathrm{C}$ & Road accident & Normal calibre vessels traced to hole \\
\hline Spizziri & 1964 & & $\mathbf{P}$ & Stick & $\begin{array}{l}\text { Tortuous arteries-dilated veins bending } \\
\text { over rim into the hole }\end{array}$ \\
\hline Kommerell & I 966 & & $\mathbf{P}$ & Hook & Vessels normal, continuous with disc \\
\hline Hart and Pilley & 1970 & & $\mathbf{P}$ & Hand & Vessels normal, continuous with disc \\
\hline Kovács & 1971 & & $\mathrm{C}$ & Explosion & Haemorrhage-poor view \\
\hline Park and others & 1972 & & $\mathbf{P}$ & Finger & Vessels normal calibre, continuous with disc \\
\hline
\end{tabular}

stage the retina was flat with circulation present in the retinal vessels. A further fall in the amplitude of the electroretinogram a-wave $(84.4$ per cent) and the b-wave ( $84 \cdot 1$ per cent) compared with the fellow eye occurred after 8 weeks when the retina detached. Our electroretinogram results do not support the theory of the existence of centrifugal fibres in the optic nerve of man, although it is possible that we may have missed an early transient supernormal response or that the retina may have been damaged by the transient vascular disturbance seen on the fourth day.

\section{Summary}

A case of traumatic complete avulsion of the optic nerve is reported together with fluorescein angi- ography and electrodiagnostic findings. Despite the disappearance of the central vessels, circulation remained in the branch retinal vessels and angiography demonstrated communication between peripapillary choroidal vessels and the superior temporal artery. The visually-evoked cortical response was abolished. Electroretinography showed a normal a-wave but reduced amplitude b-wave, not supporting the theory of the existence of centrifugal retino-suppressive fibres in the optic nerve of man.

We should like to thank Mr S. J. Crews and Mr K. Rubinstein for their helpful advice, Miss J. McCulloch for preparing the illustrations, and the patient, Miss M. J., for her co-operation during this study.

We are grateful to the Research Committee of the West Midlands Regional Health Authority for their financial support.

\section{References}

ASCHMANN (1884) Inaug. diss. Zürich (cited by Salzmann, 1903)

BIRKhäUSER, R. (19ro) Klin. Mbl. Augenheilk., 48, 432

BRINDLEY, G. S., and hamaSaki, D. I. (I 962) $\mathcal{F}$. Physiol (Lond.), 163, 558 
, and - (1966) Ibid., 184, 444

FROST, W. A. (1903) Trans. ophthal. Soc. U.K., 23, 286

GaGarin, N. W. (1904) Klin. Mbl. Augenheilk., 42, 258

GILLS, J. P. (1 966) Amer. F. Ophthal., 62, 287

GOLDSMITH, G. H. (1903) Trans. ophthal. Soc. U.K., 23, 285

GONIN, J. (I9I2) Ann. Oculist. (Paris), 147, 16

GRUBER, E. (1959) Amer. F. Ophthal., 48, 528

HART, J. C. D., and PILLEY, S. F. J. (1970) Brit. F. Ophthal., 54, 78I

HASSELT, VAN P. (1969) Ophthalmologica (Basel), 159, 65

$$
\text { (1972) Ophthal. Res., 4, } 298
$$

HESSE, R. (1907) Z. Augenheilk., 17, 45

HORSTEN, G. P. M., and WINKELMAN, J. E. (1969) Ophthalmologica (Basel), 157, 293

JaCOBSON, J. H., and GESTRING, G. F. (1958) Arch. Ophthal. (Chicago), 60, 295

—, and SUzUKI, T. A. (1962) Ibid., 67, 791

JULER, F. A. (1916) Trans. ophthal. Soc. U.K., 36, 24I

коvács, M. (197I) Klin. Mbl. Augenheilk, 158, 833

KOMMERELL, G. (1966) Ibid., 146, 880

LANG, w. (I9OI) Trans. ophthal. Soc. U.K., 21, 98

LISTER, W. T., and HINE, M. L. (I919) Ibid., 39, 196

LOEWENSTEIN, A. (1943) Brit. F. Ophthal., 27, 208

NAGAYA, T., OISHI, S., and kUNo, M. (1962) Arch. Ophthal. (Chicago), 68, 532

PARK, J. H., FRENKEL, M., DOBBIE, J. G., and ChOROMOKOS, E. (I971) Amer. F. Ophthal., 72, 969

PICHLER, A. (1910) Klin. Mbl. Augenheilk., 48, 246

salzmann, M. (1903) Z. Augenheilk., 9, 489

SPIZZIRI, L. (1964) Amer. F. Ophthal., 58, 1056

stanton-COOK, L. (1953) Brit. F. Ophthal., 37, 188

StOEWER, P. (1910) Klin. Mbl. Augenheilk., 48, 426

TREACHER-COLLINS, E. (I9I4) Trans. ophthal. Soc. U.K., 34, 190

weinstein, A. (1908) Klin. Mbl. Augenheilk., 46, 53I 